\title{
Komplexita, rituál, víra a „bytí spolu": Zdroje nejistoty a techniky jejího zvládání, prípad taneční improvizace ${ }^{1}$
}

\author{
Complexity, Ritual, Belief and "Standing By": Sources \\ of Uncertainty and Practices of its Management, \\ the Case in Dance Improvisation
}

Milan Fujda

\begin{abstract}
In this article I analyse the handling of uncertainty in dance improvisation performance. I focus on the sources of uncertainty together with techniques used to manage it. I also show that magic practices are integrated among these techniques and that all the described techniques are pragmatic and reasonable, though they do not provide guaranteed effects. This leads to an analysis of the possible role of belief in ritual practice. The efficiency of ritualist magic in handling uncertainty is ascribed to its ability to create an intimately supportive atmosphere of mutual reliability. Belief regarding the causal efficiency of magic is then shown as an issue emerging only in controversies over the nature of collective enterprise as a way of othering. The complexity of dance and life in general makes uncertainty inevitable. Hence, all theoretical knowledge in terms of consequences of action is provisional. The text then recommends rejecting the knowledge-belief dichotomy and reshaping belief to analytically comprise knowledge as intertwined with uncertainty.
\end{abstract}

KEYWORDS complexity, ritual, belief, uncertainty, dance, performance, improvisation, techniques of the body

\section{Úvod}

Antropologické ${ }^{2}$ a sociologické analýzy (zejména z oblasti studia zdraví a nemoci) se dnes kloní k chápání nejistoty jako bytostné charakteristiky lidské situace (Kleinman 2006, s. 1, 10; Jackson 1998; Viebeke, Jenkins a Jensen 2005, s. 12). Lidé zvládají nejistotu oběma ideálně typicky vymezitelnými základními zpo̊soby: jedním, založeným na důsledném plánování a managementu rizika, i druhým, založeným na přijetí nevyhnutelnosti nejistoty

Sociální studia / Social Studies 2/2020. S. 33-51. ISSN 1214-813X.

1 Př́prava tohoto článku byla podpořena grantem „Výzkumné trendy v současné religionistice“ (VYTRESOUR) řešeným Ústavem religionistiky FF MU v roce 2020.

2 Rád bych poděkoval anonymním posuzujícím za cenné připomínky k recenzované verzi tohoto textu. 
s apriorní otevřeností možnostem selhání. Oba typy strategií mají rozličné praktické důsledky a typicky jsou v každodenní praxi kombinovány.

Můj text se zaměří na analýzu zdrojů nejistoty $v$ př́pravě a performanci improvizovaného celovečerního představení současného tance. $\mathrm{V}$ tomto kontextu se bok po boku s důkladným plánováním a pečlivě promýšlenou organizací i využíváním prověřených (ne však zaručených) principů organizování tanečněimprovizační performance využívají také techniky rituálně-magické povahy. Výrazem „,magický“ zde odkazuji k antropologické tradici obtížné uchopitelnosti kauzality těchto rituálních praktik ve vztahu k požadovaným výsledkủm činností, v jejichž rámci jsou použivány. Skutečnost, že řetězec zprostředkujících činitelů vedoucích od takové rituální aktivity $\mathrm{k}$ požadovanému účinku bývá nejasný či sporný, $\mathrm{v}$ praxi nevede $\mathrm{k}$ opouštění těchto technik. Zůstávají relevantní součástí řešení problémů. Dokonce se zdá, že jsou tím důležitější, čím méně jistoty je s řešením daných problémů spojeno. Proto bývají takové techniky popisovány $\mathrm{v}$ kontextu antropologie a sociologie medicíny (Viebeke, Jenkins a Jensen 2005, s. 11; Reynolds White 2005, s. 252). To naznačuje, že ve hře není jen nejistota, ale také závažnost daného problému. To ovšem neznamená, že na jejich účinnost zúčastnění aktéři zcela spoléhají. Neznamená to nutně ani to, že pracují s nějakými vírami ve smyslu teorí́, které jejich kauzalitu objasňují.

Takové rituálně-magické praktiky tedy mají $\mathrm{v}$ jednání spojeném $\mathrm{s}$ výraznou mírou nejistoty zásadní roli. Jakou ale? Jakým konkrétním způsobem prakticky přispívají k řešení problémů? Empirická data z mého etnografického výzkumu ukazují, že pomáhají budovat kolektivní emoci sdílení a soudržnosti jako formu vzájemné podpory v nejisté komplexní situaci. V tomto smyslu hovořím o „bytí spolu“3. „Bytí spolu“ tedy vypadá jako forma zprostředkování aktivní podpůrné přítomnosti druhých osob ve společné činnosti a sdílené odpovědnosti. Zprostředkování osoby, na rozdíl od zprostředkování informace vědeckou reprezentací, je však specifickým typem zprostředkování, který Bruno Latour (2016, s. 49-51) přisuzuje náboženské řeči. Avšak zpř́ítomňování osob v rituálně-magickém zvládání nejistoty v daném terénu zcela jednoznačně neslouží $\mathrm{k}$ rozpomenutí na transformativní př́tomnost spásy, již Latour $(2010$, s. 102, 115, 119) s náboženstvím jako modem existence bezprostředně spojuje.

To vytváŕí zvláštní paradox. Rituálně-magické jednání je standardně spojováno s konceptem náboženství, jež je v sociologické tradici těsně provázáno s konceptem víry (Durkheim 2002, s. 55). Latour však prostřednictvím pojetí náboženství jakožto modu existence bezprostředně tvrdě kritizuje jeho moderní chápání. To jej uchopuje jazykem zprostředkovávání informace, což dobře vystihuje řeč vědeckou, ale $\mathrm{v}$ aplikaci na řeč náboženskou není ničím jiným než „komedií omylü“ (Latour 2010: 110-112). Koncept víry je pak produktem této komedie (Latour 2016a, s. 56-57). A na ní stojí celá sociálněvědní tradice jeho studia. Proto hovořím o paradoxu, když se v tomto textu o rituálně-magických technikách zvládání nejistoty tyto př́stupy setkávají.

A proto jsem také přesvědčen, že prozkoumání způsobu, jakým rituálně-magické techniky pomáhají prakticky zvládat nejistotu v taneční improvizaci, mě může přiblížit rozpletení tohoto paradoxu. Chci tak přispět jak (1) ke kritickému prozkoumání Latourova pojetí

„Standing by“: Tento koncept je inspirován motivem zvládnutí jakékoliv nesnáze, „dokud při mně zůstáváš“ (,just as long, as you stand by me“ v písni „Stand by me“ Bena E. Kinga z roku 1961). 
náboženství jakožto modu existence, (2) tak k ujasnění praktické role magie v životě moderních lidí, a díky tomu též (3) přinést několik důležitých, prakticky zužitkovatelných kritických podnětů ke způsobům, jimiž jsou sociální vědy zvyklé náboženství analyzovat. Při tom musím předeslat, že má argumentace a celý zájem o rituálně-magické techniky zvládání nejistoty vycházejí z mého př́klonu $\mathrm{k}$ postkoloniální tradici kritiky nakládání s konceptem náboženství v sociálních vědách a požadujícího úplné opuštění tohoto pojmu jakožto analytické kategorie (viz Asad 2003; Fitzgerald 2003, 2008; Fujda 2013). To, že uvedené praktiky v následujícím textu nebudu analyzovat samy o sobě jakožto projev „náboženství“, ale $\mathrm{v}$ logice jejich praktického využívání $\mathrm{v}$ souhře $\mathrm{s}$ dalšími postupy zvládání nejistoty $\mathrm{v}$ tanečněimprovizační performanci, je projevem tohoto opuštění kategorie náboženství. Zároveň je následující analýza ilustrací způsobu, jak konkrétně její opuštění metodologicky zvládnout, a jak doufám, také demonstrací výsledků, jaké takový postup může přinést.

\section{Nejistota komplexity}

Následující text analyzuje data $\mathrm{z}$ terénního výzkumu tanečněimprovizačního projektu, který byl zároveň pohybovým sociálním výzkumem. Probíhal v roce 2012 v jednom z větších měst České republiky. Jako etnograf jsem se stal součástí týmu, který na projektu ve svém volném čase $e^{4}$ půl roku přibližně jednou týdně pracoval. S blížícím se termínem představení pracovní nasazení nabývalo na intenzitě. Týden před představením tým trávil zkouškami v divadle a dolad’ováním představení každý den. Já trávil po celou dobu trvání projektu čas s celým týmem během tréninků, zkoušek a víkendových soustředění i s choreografkami na jejich týdenních pracovních setkáních, na nichž propracovávaly tréninkové aktivity a vhodné instrukce pro ně. Analýzou průběhu tréninkových aktivit a jejich přetvářením usilovaly o nalezení optimální struktury performance. Součástí tohoto hledání bylo to, že zkoumaly, jak se do tanečních interakcí vtělují vztahy, jež se mezi tanečnicemi utvářely. Celý tento taneční experiment byl v druhém plánu výzkumem průběhu lidské spolupráce za podmínky, že vztahy zúčastněných nejsou definovány předem. Výsledná improvizovaná performance měla tuto dynamiku rozvíjení spolupráce $\mathrm{v}$ taneční formě předvést. Propracovávání podmínek tanečních interakcí a experimentování $\mathrm{s}$ jejich principy tak nemělo vést pouze $\mathrm{k}$ vytvoření dobré struktury představení, ale také $\mathrm{k}$ tomu, že tato struktura umožní prostřednictvím improvizovaných interakcí prezentovat poznání, jak se lidé „odsouzení“ ke spolupráci chovají, jakým způsobem rozvíjejí vzájemné vztahy a jak toto rozvíjení vztahů spoluformuje naplňování společných cílů. S choreografkami a výtvarnicí, která byla iniciátorkou celého projektu, jsem také o inspiracích, cílech a pojetích projektu vedl na samém začátku rozhovory.

Zmíněná výtvarnice projekt iniciovala po nezdařeném landartovém happeningu. Happening byl považován za nezdařený v jednom konkrétním úzkém smyslu: odvíjel se totiž od komiksově zpracovaného scénáře, od něhož se ovšem většina účastníků výrazně odchýlila. Proto, aby zjistila příciny tohoto selhání, se výtvarnice spojila s choreografkami pro tento tanečněinterakční výzkum, seznámila je se svou představou projektu a dala jim volnou ruku.

4 Můj zájem vzešel z př́ležitosti, která se mi nečekaně nabídla jako vítaná možnost prověřit teoreticko-metodologické principy, na jejichž rozvíjení jsem tehdy usilovně pracoval. 
Do projektu zasahovala sporadicky a ve svém venkovském domově se věnovala tvorbě frotáží stromů, z nichž měla být vystavěna scéna závěrečné performance. Před samotnou performancí byla ve vestibulu divadla také pouštěna filmová stopáž ze zmíněného happeningu.

Součástí týmu jsem byl od počátku. S rozvíjející se prací jsem se postupně začal podílet i na tvůrčím procesu sdílením vlastních názorů během reflexivních částí tréninků. Krátce před reprízou představení jsem byl dokonce zatažen do samotné performance tím, že jsem dostal za úkol nahradit strukturu improvizace z premiéry strukturou, jíž dám představení sám prostřednictvím třech vstupů, jimiž na základě vlastní reflexe průběhu performance změním její dynamiku: předčíáním pasáží ze svého terénního deníku, předvybraných ve spolupráci $\mathrm{s}$ choreografkou.

Nejen na samém konci, ale od samého počátku byl tedy celý tento projekt $\mathrm{v}$ pohybu a překypoval komplexností. Původní představa o zjištění podmínek spolupráce a jejich překladu (viz Callon 1986) do struktury a pravidel improvizace vzala v důsledku neustálých překvapení, jež tanečnice choreografkám připravovaly, brzy za své. Pro přiblížení situace: na projektu spolupracovaly dvě choreografky (jedna tančící), šest dalších tanečnic, dva hudebníci a mezi tím jsem se ještě pohyboval já. Od všech se očekávala invence a tvưrčí zapojení. $\mathrm{Na}$ takovou míru komplexity byla představa postupného formování představení prostřednictvím reflexe promyšlených improvizačních cvičení, jež povedou $\mathrm{k}$ vycizelování pravidel a struktury řídících ve výsledku performanci, nadmíru technicistní. ${ }^{5}$ Neustálé frustrace tanečnic z toho, že nechápou, co po nich choreografky vlastně chtějí, z jejich věčné nespokojenosti s tím, jak na jejich instrukce tanečně reagují, a ze stejné frustrace choreografek $\mathrm{z}$ toho, že tanečnice na pečlivě promyšlená pravidla, omezení a úkoly reagují úplně jinak, než očekávaly, postupně vedly k úplnému otevření tvůrčího procesu pro všechny zúčastněné. Choreografky přestaly tanečnice vést a začaly $\mathrm{v}$ rovnocenné spolupráci nejen $\mathrm{s}$ nimi, ale i s muzikanty a se mnou celé představení nanovo hledat. Toto hledání se stalo demokratickým participativním procesem, v němž se každý mohl podílet na promýšlení cílů i prostředků $\mathrm{k}$ jejich naplnění. Znamenalo to také, že si všichni postupně osvojili základní záměry projektu a přijali jej za společnou věc, na jejíž kvalitě jim nesmírně záleželo.

Struktura pro premiéru sice zůstala založena na klíčových slovech vyjadřujících de facto dějovou posloupnost již původního landartového happeningu: stromy, chůze, dvojičky a trojičky, organismus a návrat ke stromům. Šlo o pohyb od samoty a klidu k následování, kopírování se, prvním kontaktům, poznávání se, rozcházení a scházení, formování vztahů, setkávání, $\mathrm{k}$ vyvrcholení v intenzivní skupinové dynamice a vyčerpání se do klidu. Avšak skutečnost, že od této struktury bylo $\mathrm{v}$ repríze upuštěno, naznačuje, že i v této minimální podobě se původní záměr ukázal problematický.

Arthur Kleinman popisuje technologicko-optimistické zvládání nejistoty jako „magickou víru v technologickou nadvládu nad životem samým“ a společně s „mýtem“ managementu rizika ji popsal jako „zcela zavádějící představu jistoty ohledně kontroly lidských záležitosti““ (Kleinman 2006: 6-7). 


\section{Zdroje nejistoty $v$ tanečněimprovizační performanci}

Kromě komplexnosti dané performačně-výzkumnou povahou projektu skýtá řadu nástrah samotná improvizovaná taneční interakce a situace improvizované performance. Tanečnice a tanečníci v ní nikdy nemají jistotu, co se v následujícím momentu stane. Musejí být připraveni $\mathrm{v}$ zásadě na neomezené spektrum možností, a tedy vědomě přítomni a soustředěni. Plánování, nějaký mikromanagement, není možné. ${ }^{6}$ Lze jen naslouchat a být připraven. $\mathrm{K}$ jisté míře redukce komplexity se standardně používá konkrétní definice omezení, která zajistí, že možné není úplně všechno, ale participanti se musejí vtlačit do nějaké těsnější formy. Ta improvizaci dává na jedné straně tvar, na straně druhé stimuluje inovativnost, nutnost nespoléhat na zaběhané pohybové vzorce. I tak ale zůstává ve hře celá řada zdrojů nejistoty, které bych v následující podkapitole rád rozebral konkrétně. Potřebuji to učinit proto, abych mohl ukázat, na co reagují techniky umožňující improvizaci a improvizovanou performanci zvládat.

Zásadní zdroje nejistoty tanečněimprovizační performance lze uspořádat do čtyř typů: 1. nemožnost dosáhnout všemi účastníky interakce sdílené definice situace; 2 . nekompatibilita odstupu a účasti, 3. mocenská asymetrie mezi tanečníky a hudebníky (tj. jistá míra závislosti tanečnic na schopnosti hudebníků zhodnotit probíhající představení a př́padně zasáhnout nějakou změnou $v$ hudbě), 4. nutnost vyvažovat aspekt uspořádanosti (tj. čitelnosti) $\mathrm{s}$ aspektem překvapení ( $\mathrm{tj}$. zajímavosti a zvratu). V následující pasáži bych se těmto čtyřem zdrojům nejistoty rád věnoval podrobněji.

\section{Absence sdílené definice situace}

Již od Williama Thomase a Floriana Znanieckiho víme, že naše aktivity probíhají jako řešení konkrétních situací, v nichž jsme se ocitli a v nichž jednáme na základě toho, jak jim rozumíme. Toto rozumění spoluformují nejen samotné podmínky interakce, ale také hodnoty uplatňované (a) v závislosti na tradici a existujících institucích, (b) na základě dosavadní osobní zkušenosti (Thomas - Znaniecki 1918, s. 68-69). Již to dává tušit, že lidské jednání $v$ různých situacích představuje komplexní dynamickou záležitost. Definice situace, tj. to, jak aktér vyhodnocuje její podmínky a s jakými postoji a záměry $\mathrm{k}$ ní přistoupí, tedy zásadním způsobem formuje každou interakci, již tak činí velmi nejistou s ohledem na její důsledky. Každou interakci! Nejen taneční. Pokud je něco specifického na improvizované interakci taneční, je to skutečnost, že - podobně jako hudební, divadelní či třeba sportovní - probíhá ve zhuštěných sekvencích bohatých na možnosti zásadních změn, které mohou přijít vmžiku. Na plánování a důkladné ověřování není čas, reakce musejí být okamžité. Jinými slovy, je prakticky nemožné, aby mezi tanečnicemi, které do interakce vstupují, docházelo instantně k vzájemnému vyjasnění definic situace. Různočtení konkrétních okamžiků bylo opakovaným tématem reflexí proběhlých aktivit, a to nikoliv pouze mezi tanečnicemi, nýbrž mezi všemi př́tomnými aktéry, tedy i hudebníky, choreografkami a výzkumníkem. Pochopitelně, hudebník ví, že hraje, a tanečnice, že tančí, stejně jako člověk v konverzaci ví, že hovoří. Již

Viz též objasnění absence možnosti mikromanagementu v jazzové hudbě (Harris 2011).

Anselm Strauss by řekl ,práce“(work) (Strauss 1993: 52). 
následující drobný pohyb ale může zpo̊sobit, že tanečník zjistí, že se svým partnerem dosud hrál úplně jinou hru, než si myslel, a musí se nově přizpůsobit.

Tento aspekt improvizace je zároveň tím, co na ní některé umělce přitahuje. Představuje pro ně výzvu jiného typu než předvedení nacvičené choreografie, jakkoliv i v té se mohou objevit nečekané situace. A zároveň do věci vnáší nejistotu. Ta ale interakce nijak neparalyzuje. ${ }^{8}$ Lidé si s ní vědí rady a dokážou v ní nacházet i zalíbení. A nakonec těmi, jejichž čtení situace rozhoduje o úspěchu a neúspěchu performance jako performance, stejně nejsou tanečníci, ale diváci. Ti, jak můžeme předpokládat na základě Garfinkelovy (1967) analýzy fungování dokumentární metody interpretace, dokážou uspořádat v zásadě cokoliv. Jenže „,cokoliv“ nemusí být představení, jež se jim líbilo, něco jim dalo, vytvořilo přijatelnou míru vzájemného porozumění a obohacení s performery. Proto úspěch představení vyžaduje od performerů péči zaměřenou na to, aby performance pro diváky byla dobře čitelná a zprostředkovávala zkušenost, již jim zprostředkovat chtějí. Techniky, jak k tomu přispět, tanečníci znají a rozvíjejí. Níže se o nich zmíním podrobněji. Takové techniky činí představení zvládnutelným, zvyšují šance na jeho úspěch, ale jejich užívání vyžaduje um a zkušenost a neposkytuje jasné záruky. Záruky ještě jakž takž existují na to, kdy představení začne, no už ne nutně ani jen na to, kdy a jak skončí. Prostřednictvím jedné takové situace bych rád ukázal, o čem hovořím, když hovořím o absenci sdílené definice situace.

Při jedné ze zkoušek představení došlo k tomu, že představení neskončilo, přestože se již ke konci schylovalo a většina tanečnic se v souladu s použitou strukturou již přesouvala do fáze „strom“, který měl performanci završit. Nečekaná drobná aktivita jedné z tanečnic však dokázala započatou dynamiku narušit tak, že přiměla ostatní k navazujícím reakcím a spustila tak nové taneční interakce:

Ukazuje se v diskusi, že všechny už měly konec, a jak došlo k tomu, že to neskončilo? No protože na to Maruščino ${ }^{9}$ plivání semínka [způsob, jakým tanečnice pojmenovaly to, co začala na jevišti Maruška v danou chvíli dělat] - Iva říkala, že měla dojem, že je tam moc ticho - začaly holky reagovat. (Terénní deník 03-06-2012)

Při premiéře představení naopak přešlo ke konci zcela nečekaně na základě zásadního různočtení konkrétní aktivity jedním z hudebníků a tanečnicí, která svou aktivitou naopak usilovala dát představení novou dynamiku, rozproudit je:

Iva pak ještě vysvětluje, jak nechtěla skončit, jenže přišla k Matyho mikrofonu a chtěla to ještě rozjet. Jenže foukla. A najednou to byl ten vítr, a tak si říkala, že je to v pr... A po čase přišel Maty, [...] říkal: „Tak je to jasný, nepochopili jsme, že už to končí, takže od Ivy přichází jasnej signál, takže jsem do toho začal taky foukat“". (Terénní deník 14-06-2012)

8 Analogicky hovoří Kleinman (2006, s. 10) o tom, že po třech dekádách své praxe jako psychiatra a antropologa, nevidí žádné známky, že by lidi paralyzovala př́tomnost nejistoty i v podmínkách utrpení, bolesti a nemoci, jimž se odborně antropologicky i psychiatricko-terapeuticky věnuje.

9 Veškerá jména uvedená $\mathrm{v}$ tomto textu jsou pseudonymy, nikoliv skutečná jména účastnic a účastníků projektu. 
Pro řešení tohoto zdroje nejistoty vlastně neexistují jiné techniky než soustředěnost, něco, co tanečníky bývá označováno jako „bdělá prítomnost“, a s nimi spojená připravenost přizpůsobit se veškerým nečekaným změnám, $\mathrm{k}$ nimž nevyhnutelně dochází. A také snaha vnímat celé jeviště se všemi dalšími aktéry, již více rozeberu v následujícím bodě. To jsou jediné prostředky, které umožňují představení dát nejen kontinuitu, ale také je fázovat. $V$ tomto př́ípadě fázování pomáhá také dohodnutá struktura, $\mathrm{k}$ níž je možné vztáhnout dění na jevišti.

\section{Nekompatibilita odstupu a účasti}

Stejně jako to zakoušíme $\mathrm{v}$ každodenních interakcích, př́lišná účast, to je vysoká míra emoční angažovanosti spojená s nedostatečnou reflexí toho, co se $\mathrm{v}$ danou chvíli odehrává i z pohledu druhého či vnějšího pozorovatele, snadno produkuje nepředvídané a nechtěné důsledky (Merton 2000). Taneční interakce je z povahy věci velmi intenzivně tělesná a vyžaduje vysokou míru soustředění, pokud má být tanečnice schopná reagovat na nečekané a rychlé změny, $k$ nimž na jevišti dochází. $Z$ toho, že je tanečnice soustředěně ponořená do interakce, a navíc vždy v těle plně vnořená do prostoru jeviště, vyplývá, že snadno ztrácí přehled o některých paralelně probíhajících situacích. I tuto charakteristiku taneční improvizace reflexe tréninkových aktivit i zkušebních a ostrých představení opakovaně zviditelňovaly.

Pro částečné zvládnutí tohoto zdroje nejistoty existuje elementární technika, již je vyžadováno začít rozvíjet hned od počátku tréninku, tj. od rozcvičky. Ani tato technika sama o sobě nic nezaručuje, její dobré zvládnutí však umožňuje představení kontinuálně dávat plynulost a čitelnost. Ǩíká se jí „naladit se na sebe“, vnímat všechny tanečnice přítomné v sále (Terénní deník 09-06-2012 aj.). Neznamená to koukat se po nich, ale blíže obtížně specifikovatelným způsobem vnímat jejich prítomnost a aktivity (Terénní poznámky 29-05-2012). Jakési tělesně-emoční vnímání se navzájem. Je to obtížně rozvinutelná technika, pro jejíž rozvíjení ovšem existují tréninkové postupy (Terénní deník 05-06-2012). Jedním z nich je chůze v prostoru. Tanečnice křižují prostorem, který je též tř̌eba (stejně jako ostatní pohybující se těla) vnímat. Proto je součástí tohoto cvičení i instrukce prostor vyplňovat. Snažit se do něj pohyb rozprostřít, zaplňovat místa prázdná a uvolňovat místa přeplněná. $\mathrm{K}$ této technice se přidružují další. Například zintenzivnění vnímání dotyku, kontaktu. Uvědomování si, kde, jak, čím dochází ke kontaktu, jaké jsou tvary tělesných částí v dotyku, jaká je stabilita druhého těla, kde se nabízejí jaké další bezprostřední možnosti a omezení pro další pohyb.

Již elementární úroveň zvládání tohoto zdroje nejistoty tak ukazuje, že řada tanečních technik je obtížně uchopitelná intelektuálně, že jsou to skutečně techniky těla a vtělené ${ }^{10}$, přesněji, zvládnutelné jako tělesné dovednosti, o nichž, jak se obvykle zdůrazňuje, není potřeba přemýšlet. Tanečnice často tvrdí, že takové reflexivní přemýšlení je spíše na škodu jejich tělesnému rozvíjení. Intelektuálně tedy není třeba či vhodné reflektovat, jak fungují. $\mathrm{Na}$ druhou stranu jsou to techniky funkční a rozvíjené pragmaticky jako elementární tanečněimprovizační performativní dovednosti.

10 K pojmu vtělenosti (embodiment) jako způsobu zrušení duality těla a duše viz (Csordas 1990, s. 8). 
Nicméně „naladěni““ řeší jen část nejistoty plynoucí z nekompatibility mezi účastí a odstupem. Tento tanečně-výzkumný projekt byl po této stránce náročný také proto, že choreografky po tanečnicích vyžadovaly výraznou emoční účast na interakcích na jevišti s tím, že tam mají být skutečně za sebe. Snaha tomuto požadavku vyhovět sváděla k zapomenutí na jeviště za horizontem individuální interakce. Ukazuje to následující projev téměř zoufalství během reflexe jedné ze zkoušek celého představení, kterou choreografka, pro všechny zúčastněné př́kvapivě, přerušila v jejím průběhu:

[J]e potřeba, abyste reagovaly jako lidi, abyste to tam hodily, jak říká Maruška a formuluje to Šárka, když se k tomu vrací asi po 10 min. diskuse. Takže Helena byla hrozně nevýrazná. Ale Helena se vrací k tomu, co už ř́íkala minule: „Jak je to možné? Jak to, že mně to přijde intenzivní, co tam dělám, a navenek to není vůbec vidět?“ (Terénní deník 03-06-2012)

A jiný komentár̆ tanečnice $\mathrm{k}$ témuž tématu vyjadřuje věc velmi pregnantně i s jejími estetickými důsledky:

[V] takovém případě, kdy si každý ujede na tom svém, to pak dopadá tak, že se tam podivně pinoží nějaké dvojičky či jednotlivci a vypadá to př́íšerně. (Terénní deník 19-11-2012)

I pro tento aspekt nesouladu však existuje řešení, opět bez záruk, ale opět naprosto pragmatické: Během improvizace občas vystupte $\mathrm{z}$ dění, třeba pomocí chůze prozkoumejte dění na jevišti a zasáhněte do interakcí, jež nevypadají dobře, a zkuste je tak odvést někam jinam. Tak znělo např́klad doporučení řeckého performera Vangelise Legakise během improvizační dílny Move the City v Brně v záríi 2012. ${ }^{11}$

\section{Mocenská asymetrie}

Mocenské asymetrie jsou obecně velkým zdrojem nejistoty, protože v sobě nesou potenciál vytváření závislosti a zneužívání. V taneční improvizaci se projevuje mocenská asymetrie mezi dvěma vrstvami performance, z nichž každá vyžaduje jiný typ smyslové aktivity. Hudbu lze snadno vnímat se zavřenýma očima, dokonce lze část jejích akustických projevů vnímat i hapticky v překladech přes další objekty i bez smyslu, jemuž je primárně dostupná - sluchu. Ne tak tanec. Tanec potřebuje aktivní zrakové vnímání. Právě tento nepoměr vytváří asymetrii, která činí tanečnice do jisté míry závislé na hudebnících.

11 Tuto taneční dílnu jsem absolvoval společně s několika tanečnicemi participujícími na projektu. Nebyla to při tom zdaleka první dílna s tímto tanečníkem, která projekt ovlivnila. Všechny v tomto textu uvedené taneční dílny, jež jsem absolvoval, jsem absolvoval společně s tanečnicemi participujícími na daném projektu, a proto jsou zápisky z nich součástí mého terénního deníku. Vedoucí těchto dílen bývali vždy zkušení performeři, u nichž tanečnice participující na projektu hledaly poučení, jež následně v rozvíjení projektu zohledňovaly. Některé z těchto dílen proběhly až po ukončení projektu a absolvoval jsem je díky tomu, že jsem v návaznosti na tento projekt začal $\mathrm{s}$ touto skupinou sám tančit. I informace $\mathrm{z}$ dílen, které proběhly později, uvádím tam, kde mi umožňují přesněji objasnit principy zvládání nejistoty v taneční improvizaci a stručně shrnují různě rozptýlená data o probíhajících reflexích dění v projektu. 
Tato asymetrie je nejvíce patrná v možnostech přinášet změnu. Pro hudebníky není snadné improvizovat společně s tanečnicemi, protože je takové partnerství obdařuje jinak nezvyklou odpovědností. Hudebník, který váhá ohledně toho, co má hrát, a čeká, až mu tanečnice svým pohybem pošle inspiraci k hraní, je strůjcem performační katastrofy. Princip je jednoduchý: jakákoliv změna, at' již v dynamice, nebo harmonii, je pro tanečnice okamžitě zaznamenatelná, a to nejen sluchem, ale právě i hapticky.

Zkušenost hudebníka je jiná. Schopnost hudebníka improvizovaně komunikovat se současnými tanečnicemi ve společných improvizovaných představeních je svého druhu odbornou specializací. Jejím předmětem je, kromě senzitivity vůči tanečnici, schopnost se s ní ,sladit““ analogickým zpo̊sobem, jako se „nalad'ují“ tanečnice vůči sobě navzájem, porozumění právě pro dynamiku změny, v níž je na smyslové úrovni silnějším hráčem. Co dělají tanečník či tanečnice, kteří si nevědí rady s hudbou a (př́ípadně v návaznosti na to) sami se sebou? Ve chvíli skutečného zoufalství, kdy tanečnice akutně potřebuje změnu, ale hudba všechny signály této potřeby ignoruje, zkouší využít hudebníkovu smyslovou linku, tj. začíná produkovat výrazné zvuky: křičet, funět, bušit do země, pleskat dlaněmi o stěnu, o vlastní tělo, dupat atd., aby mu jasně sdělila svou frustraci a přinutila jej ke změně:

Maruška pak vysvětluje muzikantům, že cítila od začátku, že je to v pytli, ale že když to tak je, tak oni nemůžou hrát podle holek, protože ony se pak samy nezvednou. Oni jsou prostě silnější, přinést změnu znamená pro tanečnici dělat něco hrozně výrazného dlouho, bouchat do země, aby si toho muzikanti všimli. Takže at' jim pomůžou. (Terénní deník 14-06-2012)

Ale jak již bylo řečeno, zásadní problém tkví v tom, zda hudebník dokáže nespokojenost tanečnice vnímat.

\section{Dynamika uspořádanosti a překvapení}

Na taneční představení, obzvlášt’ na taneční představení současného tance, mnoho diváků nechodí. Baletní představení ztvárňují obvykle příběh, jehož děj bývá zřejmý. Současný tanec, od taneční moderny přes postmodernu po současnost, je výrazně experimentální. Podobně jako současná hudba. Kánony se vědomě porušují, s formami i obsahem se experimentuje. To divákovi, který je zvyklý číst tanec jako př́běh o něčem, situaci neusnadňuje. I tanečnice ve studovaném projektu často uvažovaly o vytvoření manuálu pro diváka: Jak vnímat současný tanec? Proč nemusí mít do řeči přeložitelný význam? Jak vlastním tělem, usazeným v hledišti, prožívat tělesnou performanci odvíjející se na jevišti? Jinými slovy, současný tanec se divákovi těžko čte. Aby mu tanečnice a tanečníci pomohli, musejí do performance vtělit nějaké uspořádanosti. Být konzistentní, vytvářet vzorce, nebát se repetice, dodržovat pravidla. Jen tak se interakce na jevišti mohou stát čitelnými, být o něčem.

A přesně v tom tkví další zdroj nejistoty. Ve chvíli, kdy je performance tak čitelná, že divák vytuší v každou chvíli, co se stane o okamžik později, mění se čitelnost v nudu. Aby představení skutečně bylo o něčem, potřebuje zároveň překvapení, zvraty, nečekané situace a události, jež znovu vzbudí divákovu pozornost. Tyto dva elementy, které jdou proti sobě, je tedy třeba jemně vyvažovat: 
A Šárka pak říká, že blbé je, když ví, kam přesně půjdou - všechny to vědí, i divák to ví, a nic. Může tam pak ale přijít nějaký překvapivý moment, jako když tam Helena začala hýbat těma ramenama. Když už tedy víte, jak to bude, tak to trochu změnit. Ne to udělat celé jinak, ale posunout.“ (Terénní deník 09-06-2012)

Práce s dynamikou vytváření pravidel a struktur a jejich porušování a rozbíjení je tedy jednou z centrálních dovedností, jež bylo třeba během celého projektu v trénincích tříbit. Takže snaha vytvářet pravidla a potřeba je rozbíjet, či tendence je porušovat zcela bezelstně, také prolínala celým projektem od počátku do konce a byla běžným předmětem reflexe. Tato reflexe ještě nabývala na intenzitě s blížícím se datem premiéry, protože každý věděl, že úspěch představení je na tom závislý. Jenže řada pravidel, k nimž se docházelo a která byla pracně budována jako záchytné body, se opakovaně bortila jako domečky z karet. Následující rozmluva proběhla večer před dnem premiéry:

Markéta ještě před odchodem na jeviště tematizovala to, že v tuto chvíli už má pocit, že nemá vůbec žádnou možnost, jak ovlivnit, jak to dopadne. Že to na ní vůbec nezáleží a nedokáže to v nejmenším ovlivnit.

[...] vyprávím [jí], jak Mati [hudebník] mluvil o tom, že je to přetrénované, a o tom příměru k poli, které je moc zorané, že už je vše vyzkoušené, takže už to vlastně ani není improvizace, ale kompozice. Markéta namítá, že to vůbec nebylo zorané, že vůbec nevyzkoušely všechny možnosti. Ale šly tak hluboko, že se jim rozpadly všechny jistoty, které měly o tom, jak dělat improvizaci. Ale takhle se to, povídala Markéta, rozpadlo i Marušce. Maruška ztratila prý i radost z toho objevování s tím, jak viděla, jak dělá pořád ty samé pohyby. Stalo se to, co čekala, že se může stát po té desetihodinové improvizaci, že zcela ztratí v důsledku toho, že dělá pořád to samé, úplně radost z tance. (Terénní deník 14-06-2012)

Jenže nakonec to byla právě Maruška, asi nejzkušenější z přítomných tanečnic, která ostatní před odchodem na jeviště ujistila o pravém opaku:

Jedna z věcí, kterou Šárka [choreografka] zdůrazňovala, než šly holky na jeviště, bylo: nebojte se porušovat pravidla. Ale zdá se, že si holky - přinejmenším Maruška, největší porušovatelka, nebo aspoň ta, která měla mezi ostatními takovou pověst - uvědomily i to, že důležitá jsou ta pravidla právě k tomu, aby bylo vůči čemu se vymezit. Takže Maruška jí briskně doplnila: „Nebojte se držet strukturu.“ (Terénní deník 14-06-2012)

Totiž i v Maruščině opakování stále stejných pohybů, jež ji připravovalo o radost z tance, je element uspořádanosti. Tato uspořádanost je uspořádaností návyků, které dávají performerovi jistotu a divákovi čitelnost, ale zároveň mají potenciál ničit dynamiku potřebných změn. Toto je jeden $\mathrm{z}$ běžně reflektovaných problémů, jemuž tanečníci čelí paradoxně ale opět utužováním pravidel. Čím více restrikcí se pohybu uloží, tím více se ztěžuje spoléhání na pohybové stereotypy. $\mathrm{S}$ tímto principem pracuje řada cvičení zaměřených na rozvíjení improvizačních dovedností.

\section{Techniky ř́zení performance}

Úspěšné zvládání tanečněimprovizační performance nicméně nesestává pouze $\mathrm{z}$ technik výše uvedených. Tanečnice si pěstují též zkušenosti s tím, co pomáhá skutečně předávat sdělení, která svou performancí zamýšlejí předat. Různé tanečnice a tanečníci tyto principy 
náležité estetické komunikace formulují různě. Ne vždy je mají zformulované do důsledků a přesně uspořádané, ale kontextuálně je dokážou použivat a $\mathrm{v}$ relevantních situacích během tanečních dílen je formulují, objasňují a vytváŕejí cvičení, jež pomáhají k jejich osvojování. Takové dílny tanečnice $\mathrm{v}$ tomto projektu navštěvovaly a získané poznatky do něj vtělovaly. Dominantním principem, který se postupně rodil ve studovaném projektu, byla technika zpracování nepodarku, tedy situace, která nevyznívá konzistentně s předcházejícím děním. Principem reakce je pak princip důsledného rozvinutí nevítané změny do konzistentního tvaru, nového motivu, který se tím stane čitelným. Jde o využití nepodarku jako nabídky $\mathrm{k}$ rozvinutí něčeho nového. ${ }^{12}$

Již zmíněný Vangelis Legakis, který výrazně improvizačně pracuje s architekturou prostoru jeho kopírováním, reagováním na jeho kvality, analogicky využívá koncept konzistence a vede tanečnice a tanečníky $\mathrm{k}$ tomu, aby si neustále byli vědomi toho, co už sami v prostoru vytvořili svým pohybem, a pracovali s tím, že jej tím přetvořili a vytvořili si tak nové př́ležitosti, ale i nová omezení.

Mexická, v Německu působící performerka Citlali Huezo zase během víkendové taneční dílny v Banské Bystrici na konci ledna 2014 v analogickém duchu hovořila o „obsesi“, závazku důsledně rozvíjet jednou započaté motivy. Druhým jí zmiňovaným principem byl „konflikt", to, že na pódiu musí být napětí, musí o něco jít, nemůže to být chlácholivá pohodička. Ale i pro již zmíněnou dynamiku uspořádanosti a překvapení měla pomůcku, jižž nazývala „fragment“. Princip toho, že se improvizace skládá z menších dílů. „Když se v situaci na jevišti začínám cítit pohodlně, je čas ji opustit, aby to nebyla pro diváka nuda.“ A nakonec „risk“, který vymezuje komplexní povahu performance obecně. Znamená jít naplno a soustředěně do toho, co se na jevišti odvíjí, s tím, že to samozřejmě nemusí vyjít. (Terénní deník 31-01-2014)

Poslední zmíněný princip vrhá jasné světlo na povahu tanečněimprovizační performance: je riziková z povahy věci. A performeři jsou si toho dobře vědomi. Vědí, že žádná z uvedených technik neposkytuje záruky, že nejistota vždy zůstává přitomná. A tuto skutečnost nebagatelizují. Jediný způsob, jak ji skutečně zvládnout, je přijmout ji jako fakt a zůstat neustále ve střehu (srov. Viebeke, Jenkins a Jensen 2005, s. 9).

\section{Komplexita, rituál a „bytí spolu“}

Právě proto, že nejistotu pomocí žádné techniky nelze zcela eliminovat, je divadelní provoz protkán dalšími technikami, které s nejistotou pracují. Performance se neodvíjí ve vzduchoprázdnu. Je vložena do provozu divadla a je závislá na celé řadě dalších profesí a úkonů od prodeje lístků a poskytnutí občerstvení divákům po organizaci zkoušek, scénografii, kostýmy, svícení, architekturu jeviště i hlediště. To vše se podepisuje na diváckém prožitku. I proto

12 Jazzový hudebník Stefon Harris (2011) - tento intertextový odkaz se objevil při reflexích uvedeného problému tanečnicemi - analogický princip zformuloval ve své TEDovské přednášce / performanci v New Yorku v listopadu 2011 slovy jejího názvu: „Není chyby na pódiu“. Během ní demonstroval, že „,chyba“ v kontextu jazzového hraní, je oslyšená příležitost, podnět, na který nenásleduje adekvátní reakce. 
performeři nevystačí s dobrým zvládnutím uměleckého řemesla, jež sestává z technik rozebraných výše. Dobré zvládnutí výše zmíněných technik je nutnou, ale nikoliv dostatečnou podmínkou úspěchu. $\mathrm{O}$ něm rozhoduje řada dalších věcí, které nelze předem vyjmenovat, analyzovat a na základě toho ovlivnit. Jevišš zůstává ve svém vztahu k hledišti nevypočitatelné. Ke zvládání nejistoty na této úrovni performance jsou však opět dostupné praktiky. Jsou to ony rituálně-magické postupy zmiňované na samém začátku tohoto textu.

Jednou z takových důležitých rituálně-magických praktik je vytváření a vzájemné obdarovávání se zlomvazkami. Jak název napovídá, jedná se o zpředmětněnou formu přání „zlom vaz“. Může mít podobu úplně libovolného předmětu, drobné pozornosti, s níž si dá někdo tu práci, aby ji vyrobil, rozdal ostatním a tím je před představením potěšil a povzbudil. Jak už víme, představení, $\mathrm{k}$ němuž se schyluje, je $\mathrm{z}$ povahy věci podnikem $\mathrm{s}$ nejistým výsledkem, a povzbuzení a potěšení je tedy úplně na místě.

Obrázek 1: Tato zlomvazka je jednoduchou kostičkou z různobarevných papírů. Před představením ji všem zúčastněným, včetně mě, rozdávala jedna $\mathrm{z}$ tanečnic

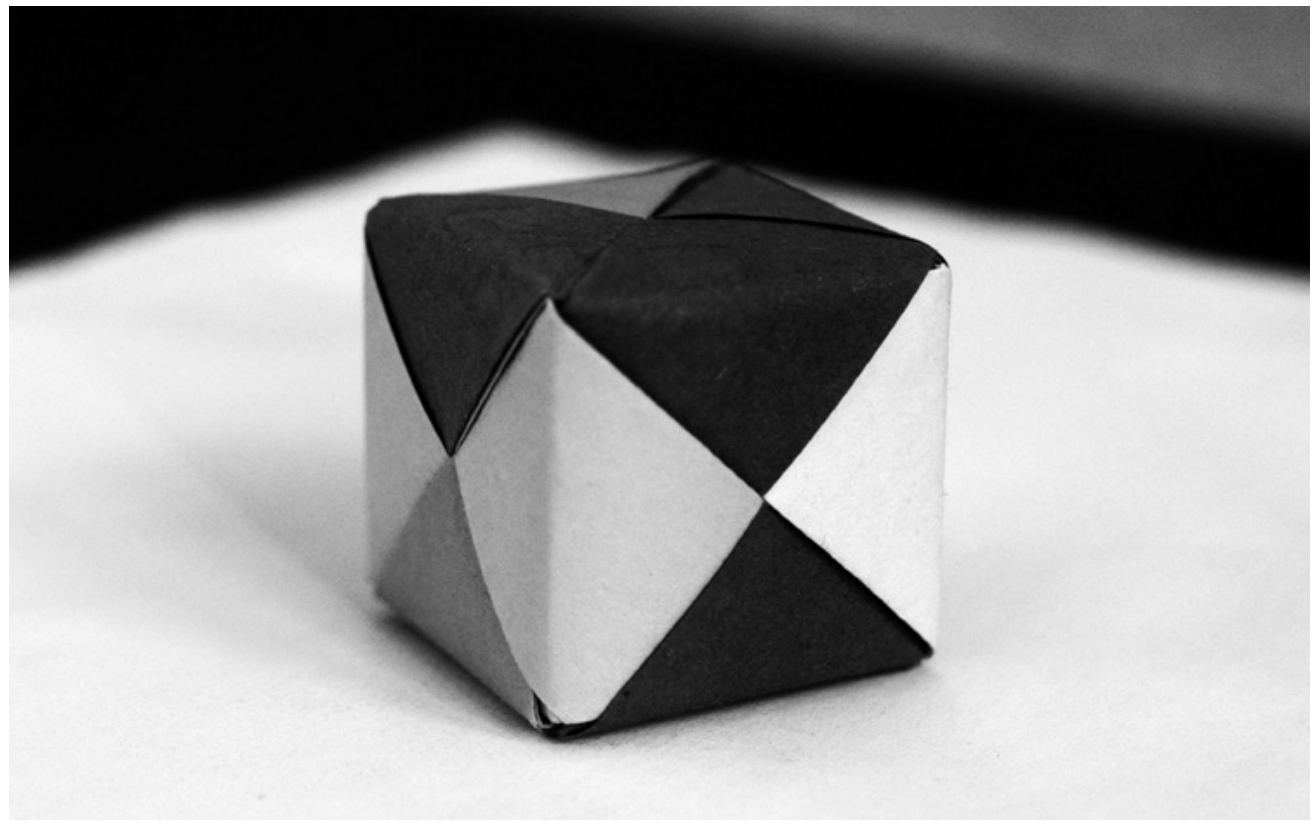

Zdroj: Archiv autora

Pravidelným úkonem, který vykonával jeden z hudebníků nejen před představeními, ale před úplně každým tréninkem, bylo vykuřování prostoru jevišš šalvějí. Očišt'ování prostoru se zejména před představením vztahovalo i na prostory šatny, kde se tanečnice, hudebníci, choreografky a já na představení chystali. 
K repertoáru povzbuzujících aktivit pochopitelně patř́ i řada forem přání si štěstí, úspěchu, dobrého konce a tradiční poplivání: „tfuj, tfuj“. Účastníci se navzájem objímají a vzduch je sycen povzbudivými slovy odhodlání a naděje v úspěch, vzájemným dodáváním odvahy, sarkastickými vtípky či prohlášeními typu, že musí vybouchnout generálka, aby pak představení bylo dobré, že naopak by to byla potíž. To vše samožrejmě již několik dní probíhalo také v prostoru sociálních sítí. Krátce před samotným odchodem na jeviště je v tom stupňujícím se zmatku třeba ještě něčeho:

Před začátkem představen, jsme se drželi za ruce $\mathrm{v}$ šatně v kruhu, což byl rituál, $\mathrm{s}$ kterým přišel Šebestián, který samozřejmě nezapomněl taky šalvějí vykouřit jeviště. Bylo to tak intenzivní, že kameraman, který to přišel točit, se mě ptal, co to je za vůni, takže jsem mu to řekl. Každopádně jsme se drželi za ruce a Šárka říkala, že neví, co má dělat, a Šebi, že nic. Takže nic, jen jsme stáli. (Terénní deník 14-06-2012)

Před druhým představením se tohoto rituálu velmi dožadovala Monika, ale začátek představení měl několik minut skluz, spěchalo se, situace $\mathrm{v}$ šatně byla nepřehledná a Moničin požadavek $\mathrm{v}$ tom chaosu zapadl.

Podstatná na tom, co tu popisuji, je skutečnost, že uvedené praktiky nejsou techné vtělující porozumění estetickým principům performačního umění. Nejsou ale o nic méně důležité. Také zjevně nejde o praktiky, které by přítomní považovali za zaručené. Představovat si, že tanečnice skutečně věři tomu, že když se chytnou za ruce, obejmou, poplivou a nevyjde jim generálka, bude mít představení zaručeně úspěch, by bylo naivní; podobně naivní jako antropolog, který byl schopný se zeptat Křováků, zda si myslí, že svým rituálem skutečně přivolali déšt' (Douglas 1966, s. 58).

Pak ale v těchto rituálech musí jít o něco jiného. Bruno Latour je z naivity, s jakou badatelé přistupují k vírám ostatních, znechucený stejně jako Mary Douglas. Snažil se proto prozkoumat pravdivostní podmínky náboženské řeči. Za to podstatné považuje skutečnost, že se v ní zpř́itomňuje něco, co vlastně prrítomné je, ale na co lze snadno zapomenout. Ztratit to ze zřetele. Děje se to analogickým způsobem, jako v otázce milenců: „Miluješ mě?“ Každý kompetentní sociální aktér ví, že odpověd’ přinášející faktickou informaci: „Vždyt’ jsem ti to řekl před pěti lety, tak přece víšc ukazuje, že něco je zle, že nedochází ke zpř́ítomnění druhé osoby a že tedy to, co se ve vztahu dosud dělo, byla lež. Intimní okamžik se rozplynul jako pára nad hrncem, protože nedošlo $\mathrm{k}$ proměně obou osob v daném momentu. $\mathrm{V}$ čase a prostoru nebyla přenesena, zpř́tomněna osoba, ale jen informace, což je úplně jiný žánr, jiný mod existence (Latour 2010, s. 102-104). Řeč, jejíž podmínky pravdivosti spočívají v tom, jak je v ní zpř́tomňována osoba, nazývá Latour řečí transformativní.

Latourův postřeh je $\mathrm{v}$ tomto ohledu perfektní. Jenže $\mathrm{v}$ jakém smyslu je přesně transformativni náboženská řeč? Transformuje osobu prostřednictvím rafinovaného zpř́tomnění skutečnosti spásy (Latour 2010, s. 112-123). A z toho jsem ted' v rozpacích. Ne proto, že Latour teologizuje. To otevřeně přiznává (Latour 2010, s. 99). Mé rozpaky vycházejí z toho, že nedokážu posoudit, zda rituální aktivity, o nichž jsem výše mluvil, mají něco společného s tím, čemu Latour říká „náboženstvi“. Jsou tansformativní a zprostředkovávají přítomnost osoby? Samozřejmě! To je důvod, proč to bez nich nejde. To zásadní, co činí, je, že přenášejí všechny prrítomné do daného momentu a místa a spojují je v intenzivní společné př́tomnosti. 
Ted' jsou tam, všichni do jednoho, spolu. A spolu udělají všechno, co svedou, ve prospěch svého představení. Všichni sdílíme tu ohromnou odpovědnost. Ale kde je spása? Prostě jsme jen tu, se svými těly z masa a kostí, se svými emocemi, napětím a rizikem, plně koncentrovaní a připravení. Do té nejistoty jdeme společně a jeden na druhého se můžeme spolehnout.

\section{Víra, nebo přesvědčení?}

Pak ovšem následuje otázka, zda uvedené formy rituálně-magické praxe vůbec vyžadují nějakou „víru“. Zda potřebují nějakou teorii toho, jak fungují: Co například přesně znamená, že je prostor očištován, je-li vykuřován šalvějí? Jak symbolické poplivání člověka nebo vyslovení slov: „zlom vaz“ způsobí št’astný průběh události? V jednom starším textu (Fujda 2016, s. 224) jsem tvrdil, že nic takového nevyžadují. To je třeba poopravit: potřeba teoretizovat ohledně fungování věcí se objevuje až při nutnosti (a) řešit palčivý problém nebo (b) řešit při spolupráci na společné věci rozpaky vyplývající z rozpoznané nekompatibility definic situace, resp. z objevivší se pochybnosti, zda stále ještě pracujeme všichni na té samé věci. Tedy z potřeby udělat si navzájem jasno. Tím prvním př́ípadem nejsem nyní schopen se dopodrobna zabývat, jakkoliv se jej dotknu tím, že se projeví v níže rozebrané situaci. Aspoň si ale nyní řekněme, že pokud mají tyto problémy povahu neštastně komplikovaných životních situací1 ${ }^{13}$, máme $\mathrm{v}$ moderní evropské kultuře $\mathrm{z}$ řady historických důvodů toto teoretizování tendenci spojovat s „náboženstvím“ (viz Berger 1967, s. 44n, Kleinman 2006, s. 14n). $\mathrm{K}$ tomu druhému prípadu bych rád ale opět přistoupil prostřednictvím svých empirických dat. Odrazím se od drobného, ale velmi nápadného rozdílu mezi tím, jak výtvarnice a jedna z choreografek prristoupily $\mathrm{k}$ mému vstupu do terénu:

Dnes něco po 16. hodině jsem volal Aleně, abych se jí zeptal, zda souhlasí s mým výzkumem $\mathrm{v}$ rámci jejich projektu. Nadšeně souhlasila, ani se neptala, co mě na tom vlastně zajímá. Říkala totiž, že jí na tom projektu zajímá jedna věc: jak si žije vlastním životem. Zdůrazňovala, že od té doby, co se ten projekt rozjel, jej nemá pod kontrolou, že si to jede samo.“ (Terénní poznámky 10-02-2012)

O několik momentů později řekla zcela jasně: „Bůh to celé organizuje“, „nikdo to nemáme v rukou“ (ibid.). Alenina reakce mě zaskočila. Odpověd’ „ano“ bez položení jediné otázky jsem nečekal. Hned vzápětí jsem se však dozvěděl, jak Alenu radikální událost dlouhodobých nepředstavitelných bolestí a blízké prítomnosti její vlastní smrti v důsledku infekce postihující CNS naučila dávat věcem volný průběh, nekontrolovat je, spoléhat se na to, že skutečné je to, co být má. Naproti tomu Šárka k celé věci přistoupila úplně jinak. Zpovídala mě ohledně detailů tématu i metodologie tři čtvrtě hodiny:

Ptala se sebe, čeho se na tom [mé účasti v projektu] vlastně bojí. Měla trochu strach, že už takhle je ten projekt dost velkej a náročnej, že tohle přináší další rovinu. Něco navíc, co je třeba koučovat. Ale zase na to nebude sama, že? Bude nás na to víc. (Terénní deník 07-02-2012)

13 Nejen Peter Berger (1967: 44n) je nazývá situace „mezní“. 
Př́stupy obou aktérek jsou zjevně nesmírně protikladné. Na jedné straně připravenost nechat věcem zcela volný průběh s důvěrou v to, že tak, jak to bude, to bude úplně správně. $\mathrm{Na}$ straně druhé snaha dostat průběh dění pod důkladnou kontrolu, kterou zvrátí až přistoupení na to, že celou situaci pro míru její komplexnosti stejně jedna osoba sama neuhlídá. Analogické odlišnosti $\mathrm{v}$ př́stupu ke světu se ovšem projevovaly $\mathrm{v}$ řadě dalších prrípadů, primárně $\mathrm{v}$ diskusích o tématu a organizaci projektu. Hlavně aby $\mathrm{z}$ toho nebyla přílišná „duchařina“, obávaly se obě choreografky po sporadických setkáních s Alenou (Rozhovory 04-03-2012 a 17-03-2012).

$\mathrm{Z}$ jejich pohledu Alena formulovala některé věci trochu moc „ezo“ (tj. ezotericky), což v nich vyvolávalo tu menší, tu větší míru diskomfortu. Přesněji, vyvolávalo to rozpaky, nejistotu ohledně toho, zda stále pracujeme na té samé věci. Zda při společné práci sdílíme společný svět (Strauss 1993, s. 41, 212n; Bowker a Star 1999, s. 193-194). Takové rozpaky nutí účastníky spolupráce vstoupit do diplomatického střetu ohledně povahy světa, na jehož tvorbě se mají společně podílet. Alena oplývala neobyčejným talentem svými formulacemi tyto rozpaky vyvolávat a v navazující konverzaci rozptylovat, takže spolupráce mohla plynule pokračovat (Terénní poznámky 23-05-2012). Bohužel pro bohatství dat, jež mám k dispozici, do projektu zasahovala velmi zřídka poté, co si jeho koncepci autorky ujasnily. Zejména Š́rku ale v samých počátcích organizace projektu svými tvrzeními, že si projekt sám najde lidi, kteří na něm budou pracovat, více stresovala než uklidňovala (ibid.). Něco jako víra tu tedy vystupuje jako čertík, který občas vyskočí z krabičky spolupráce. Má tu podobu přesvědčení, které je těžko vydobytým plodem osobní životní zkušenosti Lenky, ale pro Šárku představuje těžko stravitelnou ,duchařinu“. Je znakem něčeho, co nesdílím a co je pro mě ve spolupráci překážkou.

Latour však dobře ukazuje, jak tohoto čerta vyrobili Modernové14. Základem celého problému je zásadní podvojné nepochopení vědy a náboženství, jehož výsledkem je dichotomie faktu (předmětu, který nebyl vyroben a „reálně“ působí; je objektivní a pochází ze sféry Př́rody) a fetiše (předmětu, který byl vyroben, a proto nemůže ,reálně“ působit; je subjektivním produktem Kultury). Pojem víry následně vychází z navazujícího rozlišení mezi „věděním“ a ,iluzí. Trik, na němž je tato konstrukce vzájemných protikladů vystavěná, vězí v tom, že Modernové při reflexi vlastní praxe vždy důsledně oddělují svůj praktický život (včetně praxe vědecké produkce vědění) a svůj život teoretický (v zásadě epistemologii, která vědeckou praxi po mnoha stránkách ignoruje). Modernové pak sobě rozumí vždy v protikladu k druhým, přičemž v jejich případě provádějí vždy jeden z odsudků podle přesně opačné logiky v závislosti na tom, zda hovoří z pozice subjektu, nebo objektu. Subjekt může být bud' svobodný (reálně jednající), a pak je objekt prázdný (je čistě iluzorní konstrukcí, fetiš), nebo je objekt skutečný (fakt), ale pak subjekt není svobodný, ale je formován objekty. Vše, co je kritickému Modernovi drahé a důvěryhodné, pak vždy v jeho úvahách o sobě a o druhých umístí na seznam faktických objekti̊, které jako příčinné faktory ovlivňují nesvobodné subjekty. Vše, co se mu nelíbí a nedůvěřuje tomu, bude vždy v seznamu iluzorních objektů (fetišů), které jsou čistým konstruktem lidské fantazie. Možnost, že by něco bylo

14 Pokus o překlad Latourova výrazu „Moderns“ často užívaného zejména v Latour (1993). 
lidským konstruktem, který fakticky působí, nepřichází v úvahu. Takový seznam ale vzniká i na pólu subjektu, kde vše, čeho si Modern váží - intencionalita, svoboda, odpovědnost -, je umístěno na seznam cenností, zatímco to, čeho si neváží - mentální stavy, city, fantazie -, jde na seznam bezcenností. Podstatné opět je, že myšlenka, že něco je něčím objektivně ovlivňované, a přitom zároveň svobodné, je nemyslitelná. Koncept víry pak slouží tomu, aby Modern neviděl, že provádí vždy svůj odsudek ve vztahu k druhým přesně podle opačné logiky v závislosti na tom, z kterého z obou seznamů bere subjekty a objekty k posouzení. Přitom ještě Pasteur, podle Latoura, směle přiznával, že jeho „kvasinky kyseliny mléčné jsou skutečné, protože důkladně nastavil podmínky pro to, aby mohly vyrůst“" (Latour 2010: 17). Výzvu, aby se rozhodl mezi tím, jestli je to, co vyrostlo u něj v laboratoři, skutečné (fakt), nebo pouhý výtvor (fetiš), by nechápal. Stejně jako všichni lidé dokud „nebyli moderni““ (Latour 1993), vytvořil Pasteur faktiš, zkonstruovanou věc, která přesahuje svého tvůrce, nabývá samostatnosti. ${ }^{15}$

Jak jsem se snažil ukázat $\mathrm{v}$ průběhu celého textu, všechny praktiky zvládání nejistoty byly rozumné, pragmaticky funkční, založené na řadě zkušeností a vědění, jež v nich bylo vtěleno. A to zcela nepochybně i v prípadě mezní zkušenosti, jejímž prostřednictvím se Alena naučila nechtít upjatě kontrolovat věci, které pod kontrolou mít nemohla. U rituálně-magických technik nebylo třeba o ničem teoretizovat, protože rozpaky, jaké zažívala Šárka, jež nevěděla, co má dělat $\mathrm{v}$ kroužku, který se právě držel za ruce, byly tak bezvýznamné, že je šlo rychle zahladit. A navíc rituály fungovaly! Zpřítomňovaly osoby tak, jak měly. Lidé drželi spolu, podporovali se a mohli se na sebe spolehnout. To pochopitelně neznamená, že výše rozebírané techniky zvládání nejistoty nemohly selhat. Právě opakované selhávání různých předpokladů vedlo k usazení několika - ano, ne zcela zaručených - principů, jichž má smysl se držet. Všechna setkání choreografek byla analýzami toho, jak to či ono cvičení, pravidla, instrukce fungovaly a selhávaly a jak je tedy pro příště vylepšit. Komplexita zkrátka př́ilišné záruky neumožňuje. Ostatně první uvedený princip nejistoty v interakci - nemožnost dosáhnout úplné vzájemné shody ohledně definice situace - implikuje, že každá situace, v níž dochází $\mathrm{k}$ interakci, je komplexní a povahu jejích výstupů z principu nelze zaručit.

Pak ale skutečně rozlišení mezi vírou a věděním postrádá jakýkoliv analytický smysl. Dobré je jen jako nástroj vytváření cizího druhého (othering), jak je analyzoval Edward Said (1978, s. 54n), jeho exotizování - stejným způsobem jako koncept „náboženstvi““ (Fitzgerald 2003) -, jehož definiční součástí ostatně je (Durkheim 2002, s. 55). To, v co lze doufat, jsou jen různé míry jistoty presvědčení, s nimiž do situací a interakcí vstupujeme. Šárčin životní postoj, který ji vede ke snaze mít věci pod kontrolou, není o nic zdủvodněnější, racionálnější, více založený na opravdovém vědění než Lenky spoléhání na prozřetelnost a spokojenost s nastalým stavem věcí.

Srovnej tuto argumentaci též s kapitolami „The Constitutional Guaranties of the Moderns“, „The Power of the Modern Critique“, „The Invincibility of the Moderns“ a „What is a Quasi-Object?" (Latour 1993, s. 29-2, 35-7, 37-3, 51-5). 


\section{Závěr}

V předloženém textu jsem se pokusil ukázat, $v$ čem spočívá komplexita tanečněimprovizační performance a jaké postupy performeři využívají $\mathrm{k}$ tomu, aby si poradili s nejistotami, které jsou v ní díky této komplexitě neustále přítomné. Popsal jsem zdroje těchto nejistot společně s technikami jejich zvládání. Ukázal jsem, že nejistotami je proniknuta performance nejen po umělecké stránce jako improvizační aktivita, ale jako celá performační událost v kontextu divadelního provozu. Proto jsou k jejich zvládání využívány nejen umělecké techniky, ale také rituálně-magické praktiky.

Ani jeden typ uvedených technik působení zdrojů nejistoty nijak zaručeně neeliminuje, ale oba umožňují nejistotu zvládat tím, že akceptují její př́tomnost a vedou zúčastněné k připravenosti reagovat pečlivě, zodpovědně a soustředěně na jakýkoliv průběh dění. Nástroje rituálně-magické povahy pak navíc působí transformativně (Latour 2010, s. 102-104) v tom smyslu, že v bdělé prrítomnosti ve společné aktivitě spojují všechny účastníky dění a připomínají jim, že jsou tu spolu a mohou se na sebe navzájem spolehnout. A že díky tomu to i tentokrát společně zvládnou.

Otázkou bylo, zda je třeba, aby aktéri sdíleli též nějaké sofistikované teorie toho, jak tyto rituální praktiky fungují. Ukázalo se, že to potřeba není, dokud jejich užívání v některých účastnících nevzbudí vážné rozpaky ohledně povahy společně sdíleného světa. Až tehdy, když se takové rozpaky objeví, je třeba si povahu sdíleného světa náležitě i po teoretické stránce vyjednat, aby spolupráce mohla plynule pokračovat.

Takové rozpaky, kromě praktických potřeb, formuje koncept víry. Ten je v moderní společnosti tradičně konstruovaný $\mathrm{v}$ protikladu $\mathrm{k}$ vědění, čímž v sobě nese zcizující (othering) a exotizační náboj. $\mathrm{V}$ interakcích nabitých respektem není tento náboj vyhrocen, takže povahu sdíleného světa lze snadno vyjednat a pokračovat dál. Moderní lidé ovšem do vztahu vůči různým koloniálním subjektům a marginalizovaným př́slušníkům vlastní skupiny respekt př́liš neinvestují a mnoho si nevyř́íávají (Latour 2016), jsou přece nepřemožitelní (Latour 1993, s. 37-39). A tak se pomocí konceptu víry vymezili vůči všem těm, kteří se drží jiného vědění. Pokud ale koncept vědění vztáhneme $\mathrm{k}$ jistotě, zjistíme, že jsme dost nevyhnutelně odsouzeni k provizoriu (Jackson 1998, s. 14). K teoriím, které, jak ukázali již Thomas a Znaniecki $(1918$, s. 68) svým vymezením konceptu definice situace, vždy vycházejí z našich sociálních institucí, postojů, hodnot, sdíleného vědění, ale také z našich osobních biografií.

Proto moderní koncept víry neobsahuje žádný analytický potenciál. Prakticky dokážeme operovat jen $\mathrm{s}$ jistou variabilitou jistoty a nejistoty ohledně důsledků našeho jednání, jež zakládáme na svých přesvědčeních. Ano, přesvědčení je ten správný koncept se vším, co nese v anglickém pojmu „belief“ či „persuation“, tedy vědění i nejistotu. Všichni lidé pak rozumí situacím, v nichž se nacházejí, a jednají v nich způsobem, který vtěluje jejich reflektovaná i nereflektovaná a rozličným způsobem zdůvodněná a zdůvodnitelná přesvědčení. 


\section{Literatura}

ASAD, Talal. 2003. „What Might an Anthropology of Secularism Look Like?“ Pp. 21-66 in Formations of the Secular. Christianity, Islam, Modernity. Stanford: Stanford University Press,

BERGER, Peter L. 1990 [1967]. The Sacred Canopy: Elements of a Sociological Theory of Religion. New York - London - Toronto - Sydney - Auckland: Doubleday.

BOWKER, Geoffrey C. a Suzan Leigh STAR. 1999. Sorting Things Out: Classifications and Its Consequences. Cambridge - London: MIT.

CSORDAS, Thomas J. 1990. „Embodyment as a Paradigm for Anthropology.“Ethos 18(1): 5-47.

DOUGLAS, Mary. 1992 [1966]. Purity and Danger: An Analysis of the Concepts of Pollution and Taboo. London - New York: Routledge.

DURKHEIM, Émile. 2002. Elementárni formy náboženského života. Systém totemismu v Austrálii. Praha: Oikúmené.

FITZGERALD, Timothy. 2003. „Playing Language Games and Performing Rituals: Religious Studies as Ideological State Apparatus.“ Method \& Theory in the Study of Religion 15(3): 209-254.

FITZGERALD, Timothy. 2007. Discourse on Civility and Barbarity: A Critical History of Religion and Related Categories. Oxford - New York: Oxford University Press.

FUJDA, Milan. 2013. „Proč nestudovat náboženství: K sociologickému uspořádávání skutečnosti.“ Sociálni studia 10(3): 13-43.

FUJDA, Milan. 2015. „What Would an Informant Tell Me after Reading My Paper? On the Theoretical Significance of Ethical Commitment and Political Transparency in Symmetrical Practice of Studying Religion(s).“ Religio: Revue pro religionistiku 23(1): 57-86.

FUJDA, Milan. 2016. „From Religion to Ordering Uncertainty: A Lesson from Dancers.“ Pp. 207230 in INGMAN, Peik, Terhi UTRIAINEN, Tuija HOVI a Måns BROO (eds.). The Relational Dynamics of Enchantment and Sacralization: Changing the Terms of the Religion Versus Secularity Debate. Equinox: Sheffiled.

GARFINKEL, Harold. 1967. „Common Sense Knowledge of Social Structures: The Documentary Method of Interpretation in Lay and Professional Fact Finding." Pp. 76-103 in Studies in Ethnomethodology. New Jersey: Prentice-Hall.

HARRIS, Stefon. 2011. „There are No Mistakes on the Bandstand.“ TED: Ideas Worth Spreading. New York. Listopad 2011. Cit. 26. června 2019 (https://www.ted.com/talks/stefon_harris_there_are_no_ mistakes_on_the_bandstand?language $=$ en).

Interview (výzkumná interview).

JACKSON, Michael. 1998. Minima Ethnographica: Intersubjectivity and the Anthropological Project. Chicago: The University of Chicago Press.

KLEINMAN, Arthur C. 2006. What Really Matters: Living a Moral Life Amidst Uncertainty. New York: Oxford University Press.

LATOUR, Bruno. 1993. We Have Never Been Modern. Cambridge: Harvard University Press.

LATOUR, Bruno. 2010. On the Modern Cult of the Factish Gods. Durham - London: Duke University Press.

LATOUR, Bruno. 2016a. „Jak být ikonofilem v umění, vědě a náboženství?“ Pp. 37-63 in Tereza STÖCKELOVÁ (ed.). Stopovat a skládat světy s Brunem Latourem: Výbor z textů 1998-2013. Praha: Tranzit.cz.

LATOUR, Bruno. 2016b. „Válka světů: A co mír?“ Pp. 179-206. in Tereza STÖCKELOVÁ (ed.). Stopovat a skládat světy s Brunem Latourem: Výbor z textů 1998-2013. Praha: Tranzit.cz.

MERTON, Robert K. 2000. „Nepředvídané důsledky záměrného sociálního jednání.“ Pp. 116-131 in Studie ze sociologické teorie. Praha: SLON. 
REYNOLDS WHITE, Susan. 2005. „Uncertain Undertakings: Practicing Health Care in the Subjunctive Mood.“Pp. 245-264 in Steffen VIEBEKE, Richard JENKINS a Hanne JENSEN (eds.). Managing Uncertainty: Ethnographic Studies of Illness, Risk and the Struggle for Control. Copenhagen: Museum Tusculanum Press.

SAID, Edward. 1995 [1978]. Orientalism. London: Penguin Books.

STRAUSS, Anselm L. 1993. Continual Permutations of Action. New York: Aldine de Gruyter. Terénni deník (terénní deník autora).

THOMAS, William E. a Florian ZNANIECKI. 1958 [1918]. The Polish Peasant in Europe and America. Vol I. New York: Dover Publications.

VIEBEKE, Steffen, Richard JENKINS a Hanne JENSEN. „Matters of Life and Death: The Control of Uncertainty and the Uncertainty of Control.“ Pp. 9-29 in Steffen VIEBEKE, Richard JENKINS a Hanne JENSEN (eds.). Managing Uncertainty: Ethnographic Studies of Illness, Risk and the Struggle for Control. Copenhagen: Museum Tusculanum Press.

\section{Autor}

Milan Fujda přednáší na Ústavu religionistiky FF MU v Brně. Teoreticko-metodologicky tíhne k postkolonialismu a tradicím symbolického interakcionismu, etnometodologie a teorie aktér-sítí. Momentálně se zabývá etnografií zaměřenou na problematiku komplexity a zvládání nejistoty. Dlouhodobě soustavně teorií a metodou v religionistickém výzkumu.

Kontakt:milky@mail.muni.cz 